\title{
The Differences of T-Regulator Cells, Alanine Aminotransferase Serum and Aspartate Aminotranspherase Between Hepatitis B Chronic Patients with and without Liver Fibrosis
}

\author{
Yostila Derosa, Nasrul Zubir, Raveinal, Arnelis \\ Department of Internal Medicine, Dr. M Djamil General Hospital, Padang
}

\section{Corresponding author:}

Yostilla Derosa. Department of Internal Medicine, RSUP DR. MDjamil. Jl. Perintis Kemerdekaan Padang Indonesia. Phone/facsimile:+62-751-37771.E-mail:yostidr@gmail.com

\begin{abstract}
Background: Hepatitis $B$ is acute or chronic liver inflammation caused by hepatitis $B$ viral and can progress to hepatic chirrosis or liver cancer. Chronic hepatitis $B$ has a high risk for liver fibrosis. Chronic inflammation and liver fibrosis are interrelated processes. This study aimed to determine the differences in T-regulator cells, Alanine Aminotransferase (ALT) and Aspartate Aminotransferase (AST) between chronic hepatitis B patients with and without liver fibrosis.

Method: This study used a cross-sectional method for patients diagnosed with chronic hepatitis $B$ in the Inpatient and Outpatient Department of the Internal Medicine Department DR. M. Djamil Padang and other hospitals in Padang city for 6 months. Samples were selected by consecutive sampling according to inclusion and exclusion criteria. Liver fibrosis is identified by fibroscan. Data were analyzed by SPSS 21.0.

Results: thirty-two patients were diagnosed with chronic hepatitis $B$ and $50 \%$ had liver fibrosis. The levels of T-regulator cells in chronic hepatitis B patients without liver fibrosis were $2.08 \%$ and liver fibrosis $2.25 \%$, but this difference was not statistically significant $(p>0.05)$. Mean ALT levels in the group without fibrosis were $19 \mathrm{IU} / \mathrm{L}(7 \mathrm{IU} / \mathrm{L}-71 \mathrm{IU} / \mathrm{L})$ and liver fibrosis $61 \mathrm{IU} / \mathrm{L}(13 \mathrm{IU} / \mathrm{L}-625 \mathrm{IU} / \mathrm{L})$. The mean AST level in the group without fibrosis were $15.5 \mathrm{IU} / \mathrm{L}(10 I \mathrm{I} / \mathrm{L}-32 \mathrm{IU} / \mathrm{L})$ and liver fibrosis $35.5 \mathrm{IU} / \mathrm{L}(10 \mathrm{IU} / \mathrm{L}-476 \mathrm{IU} / \mathrm{L})$. The difference between ALT and AST in the two groups was significant $(p<0.05)$. Hepatitis B patients with liver fibrosis had higher ALT and AST levels than without fibrosis.
\end{abstract}

Conclusion: There were differences levels of T-regulator cells in the two groups, but it was not statistically significant. ALT and AST levels were higher in the liver fibrosis group and statistically significant.

Keywords: T-regulator cells, alanine aminotransferase (ALT), aspartate aminotransferase (AST), liver fibrosis

\begin{abstract}
Latar belakang: Hepatitis B adalah peradangan hati akut atau kronis yang disebabkan virus hepatitis B dan dapat berlanjut menjadi sirosis hati atau kanker hati. Hepatitis B kronik beresiko tinggi untuk terbentuknya fibrosis hati. Inflamasi kronis dan fibrosis hati adalah proses yang saling berhubungan. Penelitian ini dilakukan untuk melihat perbedaan kadar sel Tregulator, serum Alanine Aminotransferase (ALT) dan Aspartate Aminotransferase (AST) antara pasien hepatitis B kronis dengan dan tanpa fibrosis hati.

Metode: Penelitian ini dengan metode cross sectional terhadap pasien yang terdiagnosis hepatitis $B$ kronis di Instalasi Rawat Inap dan Rawat Jalan Bagian Penyakit Dalam RSUP DR. M. Djamil Padang dan RS swasta
\end{abstract}


di kota Padang selama 6 bulan. Sampel dipilih secara consecutive sampling yang memenuhi kriteria inklusi dan ekslusi. Fibrosis hati di ketahui melalui fibroscan. Data di analisa dengan SPSS 21.0.

Hasil: Sebanyak 32 pasien didiagnosa dengan hepatitis B kronik, sebanyak 50\% terdapat fibrosis hati. Kadar Sel T regulator pasien hepatitis $B$ kronik tanpa fibrosis hati 2,08\% dan fibrosis hati 2,25\%. Perbedaan antara kadar Sel T regulator pada kelompok ini tidak bermakna $(p>0,05)$. Kadar rerata ALT pada kelompok non fibrosis 19 IU/L (7IU/L-71IU/L) dan fibrosis hati 61 IU/L (13IU/L-625IU/L). Kadar rerata AST pada kelompok non fibrosis 15,5 IU/L (10IU/L-32IU/L) dan fibrosis hati 35,5 IU/L (10IU/L-476IU/L). Perbedaan kadar ALT dan AST pada ke dua kelompok ini bermakna $(p<0,05)$. Pada pasien hepatitis $B$ dengan fibrosis hati memiliki kadar ALT dan AST yang tinggi dibandingkan kelompok tanpa fibrosis.

Simpulan: terdapat perbedaan kadar sel T regulator pada kedua kelompok, namun tidak bermakna secara statistic. Kadar serum ALT dan AST lebih tinggi pada kelompok fibrosis hati dan perbedaan ini bermakna secara statistik.

Kata kunci: sel Tregulator, alanine aminotransferase (ALT), aspartate aminotransferase (AST), fibrosis hati

\section{INTRODUCTION}

Hepatitis $\mathrm{B}$ is a liver disease caused by the hepatitis B virus which causes acute or chronic liver inflammation and can progress to hepatic cirrhosis or liver cancer. It is estimated that one-third of the world's population has been exposed with this virus and 350400 million of them have hepatitis B. Approximately $10-30 \%$ of patients with hepatitis B have a higher risk of progressive chronic liver disease along with hepatic fibrosis and cirrhosis. ${ }^{1-2}$ In Indonesia, people with hepatitis B in a healthy population are estimated to reach 4.0-20.3\% with the proportion of people outside Java Island higher than Java Island..$^{2-4}$ Hepatitis B virus infects hepatocytes can cause hepatocyte cell damage and cause necrosis of liver cells so that enzymes are released from mitochondria that can be detected in the blood. Normal conditions, this enzyme is produced in the liver and released in normal levels. Increased liver enzymes are sensitive biomarkers of liver damage. Serum aspartate aminotransferase (AST) and alanine aminotransferase (ALT) levels are the most commonly used indicators of liver damage. ${ }^{5-8}$

AST is increased in damaged hepatocytes, heart, muscle, kidney, brain and red blood cells. AST is an indirect marker of hepatocellular damage and fibrosis. increased AST occurs in liver damage with severe fibrosis. AST is more sensitive but less specific than ALT. ALT is an enzyme specific to the liver and is found mostly in the liver. Elevated serum ALT is associated with damage to the hepatocyte membrane. There are several studies assessing the correlation between ALT and AST with liver necroinflammation and degree of fibrosis. Demir et al found that high levels of ALT and AST can be used as an indicator of advanced fibrois. ${ }^{9-11}$
Regulatory T cells (Tregs) function to regulate the hepatitis immune response, Tregs prevent excessive immune responses by regulating signals from antigen precenting cells (APC) or effector T cells in response to viruses. Recent studies have shown that chronic hepatitis B patients have elevated peripheral Treg levels. Expansion of Tregs against viral hepatitis contributes to an inadequate immune response, leading to precise viral infections. ${ }^{12-13}$ Langhans B et al, Treg levels are high in patients with advanced fibrosis. Treg stimulates fibrosis by releasing TGF-B which is a prophibrotic agent. $\mathrm{Li} \mathrm{x}$ et al, the percentage of Treg was significantly higher in hepatitis B patients with advanced liver fibrosis than in early liver fibrosis $(p=0.0309) .{ }^{14-15}$ Zhai et al, found higher levels of regulatory $\mathrm{T}$ cells in patients with acute on chronic liver disease (ACLF) .28 Yu X et al, decreased Treg/ Th17 ratio and increased TGFB/IL-17 were associated with disease progression in hepatitis $\mathrm{B}$ chronic patients and can be used as a marker of prognosis and disease progression. ${ }^{16}$ Based on this, the investigators were interested in knowing the differences in levels of T-regulator cells, serum ALT and AST between chronic hepatitis B patients with and without liver fibrosis.

\section{METHOD}

This study used a cross sectional method and was carried out in the Inpatient and Outpatient Installation of Internal Medicine Department DR. M. Djamil Padang and other hospitals in the city of Padang for 6 months. Samples were selected by consecutive sampling. The minimum number of samples is 13 people, in this study 16 samples were taken in each group. The sample included inclusion criteria (chronic hepatitis $\mathrm{B}$ patients who did not receive antiviral therapy in the 
last 6 months and were willing to fill in the informed consent following the study) and exclusion criteria (patients with immunodeficiency diseases; patients with hepatitis A, hepatitis $\mathrm{C}$ or drug induced hepatitis; patients with Fatty liver; patients with clinical hepatic cirrhosis and abdominal ultrasound examination and patients with fulminant hepatitis).

Diagnosis is based on history, physical examination, laboratory examination and fibroscan result. Laboratory tests that were checked were serum ALT, AST and levels of T-regulator cells. Fibroscan was used to assess liver fibrosis (without fibrosis $<8 \mathrm{kPa}$, fibrosis $\geq 8 \mathrm{kPa}<18.5 \mathrm{kPa}$, cirrhosis of the liver $\geq 18.5 \mathrm{kPa}$ ). In this research Hepatitis B patient with fibrosis is the one indicate in fibroscan showed F2-F3, and chyrrosis is the one that found F4 in fibroscan or clinically and USG fulfilled chyrrosis criteria.

The basic data which includes the characteristics of the patient is analyzed by descriptive. Categorical data are presented in terms of frequency and percentage, while numeric data are presented in terms of mean and standard deviation. Differences in serum levels of AST, ALT and T-regulator cells in chronic hepatitis patients with and without liver fibrosis were analyzed using t-test analysis. Data were processed with SPSS 21.0

\section{RESULTS}

Thirty-two people according to the criteria were divided into 2 groups with 16 people each. In the group of hepatitis patients with fibrosis, there were 16 people consisting of 10 men (62.5\%) and 6 women (37.5\%) with age less than 40 years 7 people $(43.75 \%)$ and age $>$ 40 years 9 people $(56.25 \%)$. The group of hepatitis patients without fibrosis was 16 people consisting of 8 men (50\%) and 8 women (50\%) with less than 40 years of age 9 people $(56.25 \%)$ and aged $>40$ years 7 people $(43,75 \%)$. In this study, the group with liver fibrosis found 11 people $(68.75 \%)$ had a BMI above normal and 5 people $(31.25 \%)$ were less or the same as normal, whereas in the group without liver fibrosis there were 9 people $(56.25 \%)$, BMI with or equal to normal and 7 people (43.75\%) BMI more than normal.

The mean level of T-regulator cells in chronic hepatitis B patients without liver fibrosis was $2.08 \%$ with a standard deviation of 0.99 . In the group with liver fibrosis a mean of $2.25 \%$ with a standard deviation of 1.29. Based on the Saphiro-Wilk test, the distribution of samples on T-regulator cells is not normally distributed, after the data transformation is carried out, the data is normally distributed, so that the statistical test can be carried out by an unpaired $\mathrm{T}$ test. The difference in T-regulator cell levels between chronic hepatitis B patients with and without liver fibrosis was not statistically significant $(\mathrm{p}>0.05)$.

The median serum ALT level in the group without

Table 1. Baseline characteristics

\begin{tabular}{|c|c|c|c|}
\hline \multirow{2}{*}{ Characteristic } & Liver fibrosis (+) & Liver fibrosis (-) & \multirow{2}{*}{$\mathbf{p}$} \\
\hline & n (\%) & n (\%) & \\
\hline Age (years) & $40.6(8.91)^{*}$ & $35.8(11.6)^{*}$ & \\
\hline$<40$ & $7(43,75)$ & $9(56,25)$ & $p>0,05$ \\
\hline$>40$ & $9(56,25)$ & $7(43,75)$ & \\
\hline \multicolumn{4}{|l|}{ Gender } \\
\hline Male & $10(62,5)$ & $8(50)$ & $p>0,05$ \\
\hline Female & $6(37,5)$ & $8(50)$ & \\
\hline \multicolumn{4}{|l|}{ Profession } \\
\hline Doctor & $1(6,25)$ & $1(6,25)$ & \\
\hline Nurse/midwife & $1(6,25)$ & $2(12,5)$ & \\
\hline Employees & $7(43,75)$ & $7(43,75)$ & \\
\hline Private job & $1(6,25)$ & $1(6,25)$ & \\
\hline Farmer & $1(6,25)$ & - & \\
\hline Housewives & $5(31,25)$ & $3(18,75)$ & \\
\hline $\begin{array}{l}\text { Government } \\
\text { employees }\end{array}$ & $0(0)$ & $2(12,5)$ & \\
\hline Colleger & $0(0)$ & $0(0)$ & \\
\hline Body mass index & $23.5(2.29)$ & $22.3(3.6)$ & \\
\hline$\leq$ normal & $5(31,25)$ & $9(56,25)$ & $p>0,05$ \\
\hline >normal & $11(68,75)$ & $7(43,75)$ & \\
\hline
\end{tabular}

Table 2. Mean levels of regulatory T cells in chronic hepatitis B patients

\begin{tabular}{|c|c|c|c|}
\hline Variable & $\begin{array}{c}\text { Liver fibrosis (+) } \\
\text { Mean (SD) }\end{array}$ & $\begin{array}{c}\text { Liver fibrosis (-) } \\
\text { Mean (SD) }\end{array}$ & $\mathbf{P}$ \\
\hline T-Regulator cell (\%) & $2,25(1,29)$ & $2,08(0,99)$ & $>0,05$ \\
\hline $\begin{array}{l}\text { Absolute T-Regulator } \\
\text { cell (cell/ } \mu \mathrm{l})\end{array}$ & $18,95(9,03)$ & $16,66(12,49)$ & $>0,05$ \\
\hline
\end{tabular}

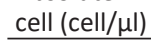

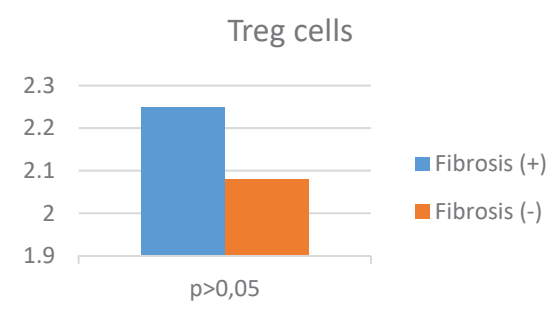

Figure 1. The difference T-regulator cell levels between chronic hepatitis $B$ patients with and without liver fibrosis

fibrosis was $19 \mathrm{U} / \mathrm{L}(7 \mathrm{U} / \mathrm{L}$ - 71U/L) while the median serum ALT level in the group with liver fibrosis was 61.6 U/L (13U/L-625U/L). Based on the Shapiro-Wilk test the distribution of ALT samples was not normal, so the Mann-Whitney test was performed and the difference in serum ALT levels between the two groups was statistically significant $(p<0.05)$.

In this study, the distribution of the AST sample was not normal with the median value of AST serum levels in chronic hepatitis B patients of $23.5 \mathrm{U} / \mathrm{L}$ $(10 \mathrm{U} / \mathrm{L}-476 \mathrm{U} / \mathrm{L})$. The median AST serum level in the group without fibrosis was $15.5 \mathrm{U} / \mathrm{L}(10 \mathrm{U} / \mathrm{L}-32$ $\mathrm{U} / \mathrm{L}$ ) while the median AST serum level in the group with liver fibrosis was $35.5 \mathrm{U} / \mathrm{L}(10 \mathrm{U} / \mathrm{L}-476 \mathrm{U} / \mathrm{L})$. 
Based on the Shapiro-Wilk test, the distribution of AST samples was not normal, so the Mann-Whitney test was carried out and it was found that the difference in AST serum levels between the two groups was statistically significant $(\mathrm{p}<0.05)$.

Table 3. Mean serum AST and ALT levels in chronic hepatitis B patients

\begin{tabular}{lccc}
\hline \multicolumn{1}{c}{ Variable } & $\begin{array}{c}\text { Liver fibrosis (+) } \\
\text { Median (min-max) }\end{array}$ & $\begin{array}{c}\text { Liver fibrosis (-) } \\
\text { Median (min-max) }\end{array}$ & $\mathbf{p}$ \\
\hline ALT serum U/L & $61,5(13-625)$ & $19(7-17)$ & $<0,05$ \\
AST serum U/L & $35,5(10-476)$ & $15,5(10-32)$ & $<0,05$ \\
\hline ALT: alanine aminotransferase, AST: aspartate aminotransferase &
\end{tabular}

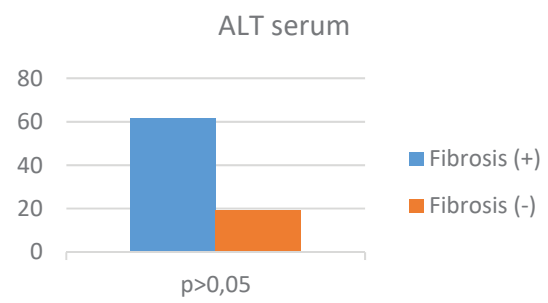

Figure 2. The difference serum ALT levels between chronic hepatitis $B$ patients with and without liver fibrosis

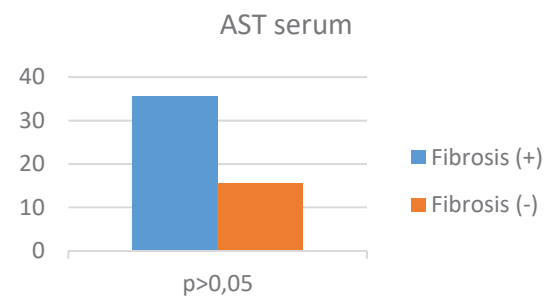

Figure 3. The difference serum AST levels between chronic hepatitis B patients with and without liver fibrosis

\section{DISCUSSION}

The mean age of hepatitis B patients in the study was 38.5 (10.06) years. This is in line with the study by Lemoine et al (2016) of 135 patients studied in Gambia, the median age of chronic hepatitis B patients was 34. (29-39). Similar to the study by Kolou M et al (2017), the prevalence of hepatitis B in the patients was $19.08 \%$. A high prevalence was found in the age group of 20-29 years $26.3 \%$ and the age between 30-39 was $21.67 \%$. The lowest prevalence was at the age of more than 50 years, namely $6,08 \% .^{18,19}$

Liver fibrosis patients were often more than or equal to 40 years, whereas in patients without liver fibrosis in the age group less than 40 years. Research by Eminler et al (2015) of 237 chronic hepatitis B patients, found a mean age of $38.38 \pm 12.14$ in the low fibrosis group and $48.40 \pm 11.17$ in the high fibrosis group. Abdo AA et al (2014) age more than 38 is a significant predictor of fibrosis with a Likelihood Ratio (LR) 1.1. The study by Tan Y et al (2015) it was concluded that age was associated with significant fibrosis, whereas multiple logistic regression analysis found that age $40-60$ years was correlated. with significant fibrosis. ${ }^{20-22}$

These results are consistent with the theory that age is associated with changes in liver morphology. Liver blood flow and liver mass decrease with age. Increased of the age also change the morphology of blood vessels, even in a healthy liver it shows defenestration of endothelial cell sinusoids, sinusoid fibrosis, increased intrahepatic arteriolar wall thickness, and decreased arteriolar diameter leading to impaired hepatocyte aerobic function. ${ }^{23}$

Based on gender, it was found that men were $56.25 \%$ and women $43.75 \%$. With fibrosis was significantly higher in men than women. Where there were 10 men $(62.5 \%), 6$ women $(37.5 \%)$. This is similar to a study by Khan et al (2011) of 1343 hepatitis B positive patients, $68.15 \%$ were male and $31.85 \%$ female. This is in line with a study by Awan et al (2010) which reported a higher prevalence in men (59.1\%) than in women $(40.9 \%)$. Male accelerated the progression of hepatitis B-related liver damage. The ratio of men to women increased from 1.2 in asymptomatic carriers to 6.3 in chronic liver disease due to hepatitis B and to 9.8 in liver cancer. This sex difference was experimentally confirmed in experiments on mice. Research by Wang et al (2015) found that androgen hormones can increase hepatitis B virus transcription. Sirinawasatien et al (2018) in a multivariate study obtained the same results, where male is a significant determinant of significant fibrosis (F2). -4) with aOR 3.24 (95\% CI: $1.36-7.72) .^{24-27}$

Montella et al (2015) informed that androgen signals can stimulate transcription and replication of hepatitis B virus genes through direct binding to the androgen receptor attachment site on HBV enhancer I (Enhancer I) of the hepatitis B virus genome, causing over-expression of HBx. HBx will activate c-Src kinase and inactivate glycogen synthase kinase (GSK3 ) which plays a role in the activation of androgen receptors. ${ }^{28}$

Reveal study shows that $\mathrm{HBeAg}$ positive and high viral load are the main keys to progression to cirrhosis and hepatocellular carcinoma. Other factors that affect the male gender are older, alcohol consumption, and high body mass index (BMI). Thus international guidelines especially recommend more aggressive antiviral therapy and close monitoring of disease progression in men over 40 years. ${ }^{29}$

In this study, the average BMI without fibrosis was $22.9 \mathrm{~kg} / \mathrm{m}^{2}$ (normal), while the BMI of patients with 
liver fibrosis was $24.05 \mathrm{~kg} / \mathrm{m}^{2}$ (overweight). This is similar to the previous study by Sirinawasitien et al (2017) that patients with significant fibrosis had a significantly higher BMI compared to minimal fibrosis, namely 25.30 (SD 4.64) versus 23.50 (SD 3.49) kg/ $\left.\mathrm{m}^{2}, \mathrm{p}=0.004\right){ }^{27}$

Research that conducted by Yen et al (2017) in a multivariate analysis study found that an increase in BMI of $1 \mathrm{~kg} / \mathrm{m}^{2}$ was an independent factor related to the change in chronic hepatitis $\mathrm{B}$ to hepatic cirrhosis (OR: 1.17; 95\% CI: 1.06-1.29, p = 0.002) ..$^{30}$

The levels of Regulatory T Cells in this study were $2.16(1.14) \%$. These levels are within normal limits. This result is different from that obtained by Lin CY et al (2007) where the Treg level in the chronic hepatitis B patients studied was $(8.9 \pm 4.11) \%$. This difference occurs due to differences in the characteristics of the sample studied where in the study Lin CY et al only examined Treg in chronic hepatitis B patients who were $\mathrm{HBeAg}$ positive. ${ }^{31}$

In this study, the Treg level in the group with liver fibrosis was $2.25(1.29) \%$ and in the group without liver fibrosis $2.08(0.99) \%$. This is different from a study by Li X et al (2017) who examined 32 hepatitis $B$ patients, the Treg cell levels in early fibrosis were $3.47 \%$ and $5.72 \%$ in advanced fibrosis. This difference occurs because in the study Li X et al did not exclude patients with hepatic cirrhosis and liver cancer. ${ }^{15}$

Weakness in this research is can not distinguish $\mathrm{T}$ cell regulator in every phase of chronic hepatitis $\mathrm{B}$ because of difficulty in getting sample in this research. Other factors that may affected $\mathrm{T}$ cell regulator are autoimun disease, Hepatitis mixed infection, or HIV, and usage of antiviral drugs had been excluded from this research.

Serum ALT levels in this study were 25.5 (7-625) $\mathrm{U} / \mathrm{L}$. This result is within normal limits. In the group without fibrosis, serum ALT levels were 19 (7-53) U / L. In the group with fibrosis, serum ALT 61.5 (13-625) $\mathrm{U} / \mathrm{L}$ was obtained. This is in line with Lemoine et al (2016) in the low fibrosis group ALT $37 \pm 25 \mathrm{U} / \mathrm{L}$. and in the significant group fibrosis $64 \pm 79 \mathrm{U} / \mathrm{L} .{ }^{18}$

Kirisci et al (2016) found that, from 172 hepatitis B patients studied, 63 patients (36.6\%) women and 109 $(63.4 \%)$ men with a mean age of $39.39 \pm 13.4$ years. Based on the degree of fibrosis, there were $122(70.9 \%)$ patients with mild fibrosis and $50(29.1 \%)$ patients with advanced fibrosis. Age, serum ALT and serum AST and HBV DNA were significantly higher in the group with advanced fibrosis $(\mathrm{p}=0.034, \mathrm{p}=0.002, \mathrm{p}$ $=0.0001$, and $\mathrm{p}=0.007) .{ }^{32}$
The serum AST level in this study was 23.5 (10 $-476) \mathrm{U} / \mathrm{L}$. This result is within normal limits. These results are the same as research by Li Q et al (2018), which examined 365 chronic hepatitis B patients with AST levels of 24 (20-29) U/L. In the group without liver fibrosis, the median serum AST level was 15.5 (10-32) U/L. Research by Lemoine et al (2016) in 82 patients with fibrosis F0-1 obtained an average AST level of $39 \pm 22 \mathrm{U} / \mathrm{L}$. In the group with fibrosis 43 (10- 476) U/L. ${ }^{18,33}$

In this research ALT level increase 15 times higher than normal, and so does AST level. This research aims only to find the difference of AST and ALT level in fibrotic and non fibrotic patients using elastography trancient method. Research by Rong San et al in 2016 showed AST and ALT did not have significant correlation with LSM (liver stiffness measurement) in chronic hepatitis B patient. ${ }^{34}$ Eman Rewisa et al, in 2016 conclude that ALT have positive correlation with LSM in acute hepatitis B patient. To minimalize the effect of severe inflammation in this research, hepatitis fulminat patient have been excluded. ${ }^{35}$

Compared to ALT, AST is more sensitive but less specific in detecting liver damage. AST normally can also be found in various tissues such as liver, heart, muscle, kidney and brain. AST is released into the serum if there is damage to these tissues. An increase in serum AST without an increase in ALT represents the most frequent breakdown of extrahepatic tissue from muscle damage. However AST can be found in the cytosol and mitochondria of liver tissue. Cytosolic enzymes are released in reversible and irreversible damage to the hepatocyte membrane and their levels increase in parallel with the increase in ALT. For example, in mice with ischemic cells with minimal damage to membrane integrity only causes membrane swelling, and does not cause mitochondrial AST damage. In fact, liver cell ischemia does not cause loss of mitochondrial AST (mAST) until all cytosolic AST (cAST) is damaged. Thus, the increase in ASTactivity is likely the result of severe and irreversible hepatocellular damage by releasing mAST reserves. So that when there is damage to sinusoid cells due to fibrosis, it will result in an increase in AST. Alanine aminotransferase (ALT) is an enzyme specific to the liver and is mostly found in the liver. High serum ALT has a high sensitivity to inflammation, necrosis, primary tumors and vacuolar hepatopathy $(80-100 \%)$. AST is more sensitive but less specific than ALT, so the increase in AST is most likely to occur only in liver damage with severe fibrosis. AST is an indirect marker 
of hepatocellular damage and fibrosis. There have been several studies assessing the correlation between ALT and AST, with liver necroinflammation and degree of fibrosis. Ozkara et al 2011 found a relationship between serum ALT, AST and the Histological Activity Index. Demir et al found that high levels of ALT and AST can be used as an indicator of advanced fibrosis. ${ }^{10}$

Based on the Mann-Whitney test, $\mathrm{p}$ value $>0.05$ was obtained, there was no significant difference between Regulator $\mathrm{T}$ cell levels between chronic hepatitis B patients with and without liver fibrosis.. This is different from research that conducted by Li X et al (2017) where there was a significant difference in levels of regulatory $T$ cells between patients with early and advanced liver fibrosis $(p=0.03)$. This difference may occur due to different techniques in examining the degree of fibrosis in the patients studied. Li X et al classified the degree of fibrosis by liver biopsy, whereas in this study a grade assessment of liver fibrosis was based on TE. In addition, patients with hepatic cirrhosis and hepatocellular carcinoma were also not excluded in the study by Li X et al. ${ }^{15}$

Aleem AA et al (2011) studied differences in levels of regulatory $\mathrm{T}$ cells between chronic hepatitis $\mathrm{B}$ patients with hepatocellular cancer, hepatic cirrhosis and normal controls, obtained Treg levels of 6.76 $\pm 2.3 \%, 2.8 \pm 1.2 \%, 1.2 \pm 0.7 \%$, respectively, $\mathrm{p}<$ 0.05. ${ }^{36} \mathrm{Li} \mathrm{X}$ et al (2017) concluded that, treg can interfere with innate and acquired immune responses by suppressing the immune response through antigen presenting cells (APC), natural killer (NK) cells, $\mathrm{T}$ cells and $\mathrm{B}$ cells. that there is a relationship between increased Treg cells and tumor progression, impaired tumor immunity and low survival rates. Tregs influence the interaction between NK cells and hepatic stellate cells by secreting soluble factors, causing changes in liver fibrogenic activity and contributing to fibrogenesis by regulating prophibrogenic markers in hepatic stellate cells. TGF $\beta$ produced by CD 4 + Foxp3 + Tregs will exacerbate fibrosis through the activation of liver stellate cells. ${ }^{15}$

Inflammation of the liver and imbalance of immunological processes in the liver are the main causes of progression of hepatitis B to liver cirrhosis. The accumulation of extracellular matrix is the main key in the progression of liver cirrhosis. When the hepatocyte infection by the hepatitis B virus, will occur an imological reaction will occur which causes inflammation which then activates the liver stellate cells, then there is a buildup of the extracellular matrix, an increase in collagen production occurs, and an abnormal buildup of the extracellular matrix occurs which can develop into fibrosis and progress to liver cirrhosis. ${ }^{15}$

In this study, there was a difference in serum ALT levels between chronic hepatitis B patients with and without liver fibrosis. Based on the Mann-Whitney test, the $p$ value was $<0.05$. This is the same as a study by Eminler et al (2015) that ALT levels in hepatitis B patients with high fibrosis were higher than low fibrosis $(97.98 \pm 93.06) \mathrm{U} / \mathrm{L}$ vs. $(68.37 \pm 57.97) \mathrm{U} / \mathrm{L} .{ }^{18}$

By using the Mann-Whitney test, there was a statistically significant difference $(p<0.05)$ in AST serum levels between chronic hepatitis B patients with and without liver fibrosis. Demir et al (2014) showed that patients with significant fibrosis had higher ALT and AST levels than patients with low fibrosis and this was statistically significant $(\mathrm{p}<0.05)$. This is in accordance with the literature where in hepatitis B patients with advanced fibrosis, further cell damage occurs so that damage occurs at the mitochondrial level which is marked by an increase in the transaminase enzyme in the liver, especially AST. ${ }^{37}$

Kirisci et al (2016) informed that ALT and AST are higher in patients with severe fibrosis compared with patients with mild fibrosis. There is a significant correlation between fibrosis and ALT and AST. Based on the regression analysis AST is a risk factor for fibrosis (sig: 0.035), and ALT and AST are risk factors for increased Knodell HAI (sig: 0.049 and 0.009). ${ }^{11}$

There were some imitations in this study, such as the levels of Regulator $T$ cells were not differentiated in the various phases of chronic hepatitis B infection. This study did not examine the factors that cause Treg balance such as effector $T$ cells, virus genotype and HBV DNA levels. The levels of regulatory $T$ cells studied were the percentage of regulatory $\mathrm{T}$ cells against CD4 + lymphocytes instead of absolute regulatory $\mathrm{T}$ cells which were influenced by many factors other than hepatitis B infection.

\section{CONCLUSION}

The average Treg level in chronic hepatitis B patients with liver fibrosis was within normal limits. The mean Treg levels in chronic hepatitis B patients without liver fibrosis were within normal limits. Serum ALT and AST levels in chronic hepatitis B patients without liver fibrosis are within normal limits. Serum ALT and AST levels in chronic hepatitis B patients with liver fibrosis are in the normal to high normal range. Treg levels were higher in chronic hepatitis B patients with 
liver fibrosis than without liver fibrosis. This difference was not statistically significant. Serum ALT and AST levels were higher in chronic hepatitis B patients with liver fibrosis than without liver fibrosis. This difference was statistically significant.

\section{REFERENCES}

1. Lesmana CR, Hasan I, Gani RA, Sanityoso A, Setiawan PB, Djumhana A. Konsensus nasional penatalaksanaan hepatitis B di Indonesia 2017.eds: Lesmana CR. PPHI:Jakarta 2017.p.1-82.

2. Tedjha MD. Genetic diversity of hepatitis B virus in Indonesia: epidemiological and clinical significance. Thesis. Utrecht University; 2012.

3. Arnelis, Julius, Zubir N, Miro S, Siburian M. Distribution of hepatitis B virus (HBV) genotype among different ethnics hospitalized in M. Djamil Hospital, Padang (Continued study) dalam naskah lengkap Konas XIV PGI. In PEGI, PIN; 2009; Bali.

4. Julius, Thedja M, Arnelis, Miro S, Zubir N. Distribution of serotype and genotype in West Sumatera revisiting adr-zone in West Indonesia. Hepatol Int 2008;2:c20.

5. Lamontagne R, Bagga S, Bouchard MJ. Hepatitis B virus molecular biology and pathogenesis. Hepatoma Res 2016;2:163-86.

6. Seeger C, Mason Ws. Molecular biology of hepatitis B virus infection. Virology 2015; 0:672-86.

7. Zentella MLC, Munoz RH. Is Liver enzyme release really associated with cell necrosis induced by oxidant stress? Oxid med and cell longev 2016;2016:1-12.

8. Kasarala G, Tillmann HL. Standard liver tests. Clin Liver Dis 2016;8:13-8.

9. Giannini E, Testa R, Savarino V. Liver enzyme alteration : a guide for clinicians. CMAJ 2005;172:367-78.

10. Ozkara, Tosun, Sari, Kilic G, Akera V, Sezikli, et al. The correlation of serum transaminase values with fibrosis staging and necroinflammatory activity. Turkiye Klinikleri J Med Sci 2011;31:68-74

11. Demir NA, Kolgelier SK, Ozcimen, Gungor G, Sumer, Inkaya $\mathrm{C}$, et al. Evaluation of the relation between hepatic fibrosis and basic laboratory parameters in patients with chronic hepatitis B fibrosis and basic laboratory parameters. Hepat Mon 2014;14:1-5.

12. Shen C, Yan WZ, Zhao CY, Che HH, Liu XY, Liu ZZ, et al. Increased CD4+CD25+ regulatory $T$ cells correlate with poor short-term outcomes in Hepatitis B virus-related acute-Onchronic liver failure patients. J Microbiol Immunol Infect 2015;48:137-46.

13. Stoop JN, Molen RG, Baan CC, Laan RJ, Kuipers RJ, Kusters $\mathrm{JG}$, et al. Regulatory T cells contribute to the impaired immune response in patients with chronic hepatitis B virus infection. Hepatology 2005;41:771-78.

14. Langhans B, Krämer B, Louis M, Nischalke HD, Hüneburg $\mathrm{R}$, Staratschek-Jox A, et al. Intrahepatic IL-8 producing Foxp $3^{+} \mathrm{CD}^{+}$regulatory $\mathrm{T}$ cells and fibrogenesis in chronic hepatitis C. J Hepatol 2013;59:229-35.

15. Li X, Xu Y, Hua X, Xi C, Liu J, Huang Y, et al. Levels of hepatic Th17 cells and regulatory $\mathrm{T}$ cells upregulated by hepatic stellate cells in advanced HBV-related liver fibrosis. Journal of Translational Medicine 2017;15:1-11.
16. Zhai S, Zhang L, Dang S, Yu Y, Zhao Z, Zhao W, et al. The Ratio of Th-17 to Treg cells is associated with survival of patients with acute-on-chronic hepatitis B liver failure. Viral Immunology 2011;24:303-09.

17. Yu X, Guo R, Ming D, Su M, Lin C, Deng Y, et al. Ratios of regulatory $\mathrm{T}$ cells/T-helper 17 cells and transforming growth factor- $\beta 1$ /interleukin- 17 to be associated with the development of hepatitis B virus-associated liver cirrhosis. J Gastroenterol Hepatol 2014;29:1065-72.

18. Lemoine, Shimawaka, Nayagam S, Khalil M, Suso P, Lloyd $\mathrm{J}$, et al. The gamma glutamyl transpeptidase to platelet ratio (GPR) predicts significant liver fibrosis and cirrhosis in patients with chronic HBV infection in West Africa. Gut 2016;65:1369-76.

19. Kolou M, Katawa G, Salou, Gozo-Akakpo K, Dossim S, Kwarteng, et al. High prevalence of hepatitis B virus infection in the age range of 20-39 years old individuals in Lome. Open Virol J 2017;11:1-7.

20. Eminler T, Ayyildiz T, Irak K, Kiyici M, Gurel S, Dolarc, et al. AST/ALT ratio is not useful in predicting the degree of fibrosis in chronic viral hepatitis patients. Eur J Gastroenterol Hepatol 2015;27:1361-6.

21. Abdo AA, Bzeizi KI, Babatin MA, Alshohaibani, Almana H, Alsaad KO, et al. Predictors of significant fibrosis in chronic hepatitis B patients with low viremia. J Clin Gastroenterol 2014;48:50-6.

22. Tan Y, Ye Y, Zhou X, Chen 1, Wen D. Age as a predictor of significant fibrosis features in HBeAg-negative chronic Hepatitis B virus infection with persistently normal alanine aminotransferase. PLoS ONE 2015;10:1-16.

23. McPherson S, Hardy T, Dufour JF, Petta S, Romero GM, Allison M, et al. Age as a confounding factor for the accurate non-invasive diagnosis of advanced NAFLD fibrosis. Am J Gastroenterol 2017;112:740-51.

24. Khan F, Shams S, Qureshi ID, Israr, Khan H, Sarwar M, et al. Hepatitis B virus infection among different sex and age groups in Pakistani Punjab. Virol J 2011;8:1-5.

25. Awan Z, Idrees M, Amin I, Butt S, Afzal S, Akbar H, et al. Pattern and molecular epidemiology of Hepatitis B virus genotypes circulating in Pakistan. Infection, Genetics and Evolution 2010;10:12-46.

26. Wang SH, Chen PJ, Yeh SH. Gender disparity in chronic hepatitis B: Mechanisms of sex hormones. Journal of Gastroenterology and Hepatology 2015;30:1237-45.

27. Sirinawasatien A, Techasirioangkun T. Prevalence determinants of significant liver fibrosis by vibration-controlled transient elastography in Thai chronic Hepatitis B patients.. Int J Hepatol 2018;2018:1-7.

28. Montella M, D’Arena G, Crispo A, Capunzo M, Nocerino F, Grimaldi M, et al. Role of sex hormones in the development and progression of Hepatitis B virus-associated hepatocellular carcinoma. International Journal of Endocrinology 2015;2015:1-10.

29. Chen C, Yang H. Natural history of chronic hepatitis B REVEALed. J Gastroenterol Hepatol 2011;26:628-38.

30. Yen Y, Ming c, Tsai M, Tseng P, Lin M, Wu C, et al. Elevated body mass index is a risk factor associated with possible liver cirrhosis across different etiologies of chronic liver disease. Journal of the Formosan Med Association 2018;117:268-75.

31. Lin CY, Tsai MC, Huang CT, Hsu CW, Tseng SC, Tsai IF, et al. Liver injury is associated with enhanced regulatory T-cell activity in patients with chronic hepatitis B. Journal of Viral Hep 2007;14:503-11. 
32. Kirisci O, Paksoy T, Caliskan A, Analan A, Ozkaya E, Kirmaci, et al. The relationship between serum DNA levels and serological markers, ALT and AST with liver histology in chronic hepatitis B patients. Acta Med Mediterranea 2016;32:1805-12.

33. Su ZJ, Yu XP, Guo RY, Ming DS, Huang LY, Su ML, et al. Changes in the balance between Treg and Th17 cells in patients with chronic hepatitis B. Diagnostic Microbiology and Infect Dis 2013:76:437-44.

34. Shan R, Yin H, Yang W, Li J, Zhang M, Zhao M, et al. Influencing factors of transient elastography in dtetcting liver stiffness. Experimental and therapeutic medicine 2016:2302-6.

35. Rewisha E, Badran H, Gamil K, Metwally K, Sameea EA, Jaky $\mathrm{AE}$, et al. Increased liver stiffness measurement values using transient elastography in Egyptian patients with acute viral hepatitis. Gastroenterol Hepatol Open acces 2016;5:00145.

36. Li Q, Zhou Y, Huang CH, Li W. A novel diagnostic algorithm to predict signifcant liver infammation in chronic hepatitis $B$ virus infection patients with detectable HBV DNA and persistently normal alanine transaminase. Scientific Reports 2018;8:1-7.

37. Dayan S, Dal T, Tekin R, Deveci O, Ipek D, Ozcan N, et al. Non-invasive parameters in the assessment of liver fibrosis. Biomed Res 2017;28:2180-84. 